\title{
NUTRITIONAL REGULATION OF IGF-I AND IGF BINDING PROTEINS
}

\section{David R. Clemmons and Louis E. Underwood}

Departments of Medicine and Pediatrics, University of North Carolina, Chapel Hill, North Carolina 27599

KEY WORDS: IGF-I, somatomedin-C, protein synthesis, growth factors, nitrogen halance

\section{CONTENTS}

Autocrine, Paracrine, and Endocrine Actions of IGFs.......................... 395

Nutritional Control of IGF-I Synthesis and Secretion .............................. 396

Nutritional Control of Plasma Concentrations of IGF-I in Humans.................. 400

Insulin-like Growth Factor Binding Proteins and Nutrition ....................... 405

Control of IGF Action by Binding Proteins .................................... 407

Summary ................................................................ 408

The insulin-like growth factors (IGF-I and IGF-II) are small polypeptides $\left(M_{\mathrm{r}}\right.$ $\sim 7500$ ) that control growth of multiple cell types. Cells derived from all three embryonic lineages contain IGF receptors, and almost all cell types have been shown to respond to IGFs (79). The IGFs stimulate multiple cellular responses that are related to growth, including synthesis of DNA, RNA, and cellular protein (80). IGF-I and IGF-II signal cells that adequate nutrient is available in the microenvironment for the cell to enter the "s" phase of the cell cycle (71). Experiments conducted in Balb/c 3T3 fibroblasts have shown that when nutrients are deficient (usually, essential amino acids), the addition of IGF-I is sufficient to overcome growth arrest in the fibroblasts (41). Support for the concept of nutrient-dependent growth signalling derives from the observation that the IGFs stimulate both amino acid transport (40) and protein synthesis (64) in skeletal tissues and have the potential to fulfill an important role as mediators of tissue anabolism.

The strongest support for the theory that the IGFs are major mediators of 
nutrient-induced changes in anabolic responses comes from the studies that have analyzed IGF synthesis and secretion. The rate of IGF-I synthesis in tissues and its secretion into the systemic circulation is dependent not only upon pituitary growth hormone but also upon the availability of adequate nutrient intake. Administration of growth hormone to fasted rats or humans results in a smaller increase in plasma IGF-I concentration (60) than is observed when growth hormone is given to fed animals. Control of IGF synthesis and secretion, therefore, may provide an intermediate signalling mechanism that indicates to target cells that adequate nutrients have been ingested and are available for protein synthesis and cell division.

Current understanding of the molecular mechanisms by which the IGFs act as an intermediate signal has resulted from the unraveling of a complex series of biochemical events that occur following nutrient intake. These studies have also clarified the relationship between IGF-I and insulin in nutrient-dependent signalling. IGF-I and insulin are structurally related: The amino acid sequence of proinsulin has about $50 \%$ homology with IGF-I (61). At one time a primordial precursor for insulin and IGF-I may have linked nutrient intake directly to stimulation of cell growth. Insulin probably evolved in order to provide a mechanism for sensitive control of carbohydrate balance following meals, whereas IGF-I has remained a more primordial stimulus that is closely related to total energy and protein intake.

The conservation of the primary structures of IGF-I and insulin allows for some overlap in their receptor specificity (52). Thus, insulin can bind IGF receptors with approximately $1 \%$ the affinity of IGF-I. In several test systems, however, insulin is not as potent a growth stimulant as IGF-I, even at concentrations that appear to be sufficient to saturate IGF-I receptors. Some additional property, therefore, may be possessed by the IGF-I molecule that permits maximal stimulation of cell growth. Likewise, IGF-I and -II can cross-react with insulin receptors by approximately $2 \%$, and IGF-I produces hypoglycemia if given in sufficient amounts (65). IGF-I, however, is not a potent stimulator of lipogenesis, presumably because fat cells do not contain IGF-I receptors (82). There is also significant conservation of structure between the insulin receptors and IGF receptors: $40 \%$ of the primary sequence of these receptors is homologous, as is their heterotetrameric structure (78). The insulin/IGF receptor heterotetramers are composed of two alpha subunits $\left(M_{\mathrm{r}} \sim 135,000\right)$ that contain either IGF- or insulin-binding sites and two beta subunits $\left(M_{\mathrm{r}} \sim 95,000\right)$ that contain a tyrosine kinase signalling domain. After binding of either ligand to its respective receptor, the receptor undergoes a confirmational change that results in activation of tyrosine kinase activity and phosphorylation of specific proteins believed to be essential for IGF and insulin receptor signalling (38). There is also evidence of receptor cross-talk: activation of the IGF receptor results in activation of the insulin receptor and 
vice versa (39). Therefore, while they have evolved specific functions concerned with mediating the effects of nutrient intake on growth and metabolism, the IGFs and insulin overlap binding and signal transduction properties. This overlap suggests that the interactions between these peptides that are involved in nutrient-dependent signalling mechanisms may be coordinated.

\section{Autocrine, Paracrine, and Endocrine Actions of IGFs}

To understand the role of IGFs in mediating the effects of nutrient intake on anabolic responses, it is important to realize that IGFs may function as autocrine/paracrine growth factors as well as classic endocrine hormones. Initially the IGFs were believed to be systemic growth factors, which are low in patients with growth hormone deficiency and high in patients with growth hormone excess (26). Later studies showed that many cell types in culture, including human fibroblasts, could secrete IGFs $(1,17)$ and that fibroblastrelated connective tissue cells in many organs contain IGF-I and IGF-II mRNAs (30). Since these cells are present in multiple tissues and organs, investigators have hypothesized that IGFs are secreted in the microenvironment and stimulate cell growth locally (Figure 1). Further support for this hypothesis derives from the observation that addition of antibodies to IGF-I or to type I IGF receptors in concentrations sufficient to inhibit IGF-I binding to receptors will block the effects of locally secreted IGF-I on growth $(10,63)$. This hypothesis has been extended by showing that IGF-I is synthesized in wound injury models of cartilage, muscle, or arteries. This synthesis occurs in cell types that are dividing rapidly (e.g. satellite cells in muscle) and continues until the wound is healed (62). Synthesis of IGF-I, therefore, may be an important component of their local proliferative response to injury, and autocrine/paracrine secretion of IGF-I may be an essential growth regulatory event after injury. Nutritional intake could potentially regulate this local proliferative response by modulating IGF-I synthesis by cells in the regenerating tissue. This review focuses on control by nutrients of IGF secretion into blood. The reader, however, should keep in mind that synthesis IGF-I in peripheral tissues (about which little is known) may also be an important component of the response to changes in nutrient intake.

The role of insulin-like growth factor II in mediating the effects of IGFs is incompletely understood. Possibly, IGF-II modulates nutritional effects indirectly, since its concentrations in serum are 3-4 times greater than those of IGF-I, and changes in IGF-I that result in saturation of plasma-binding proteins might accelerate the rate of IGF-II transport out of the vascular compartment. Changes in extravascular IGF-I concentrations could also change IGF-II binding to cell surface receptors. IGF-II has $52 \%$ amino acid sequence identity with IGF-I and binds the type I IGF receptor with approximately one third the affinity of IGF-I (56). Therefore, IGF-II has the struc- 


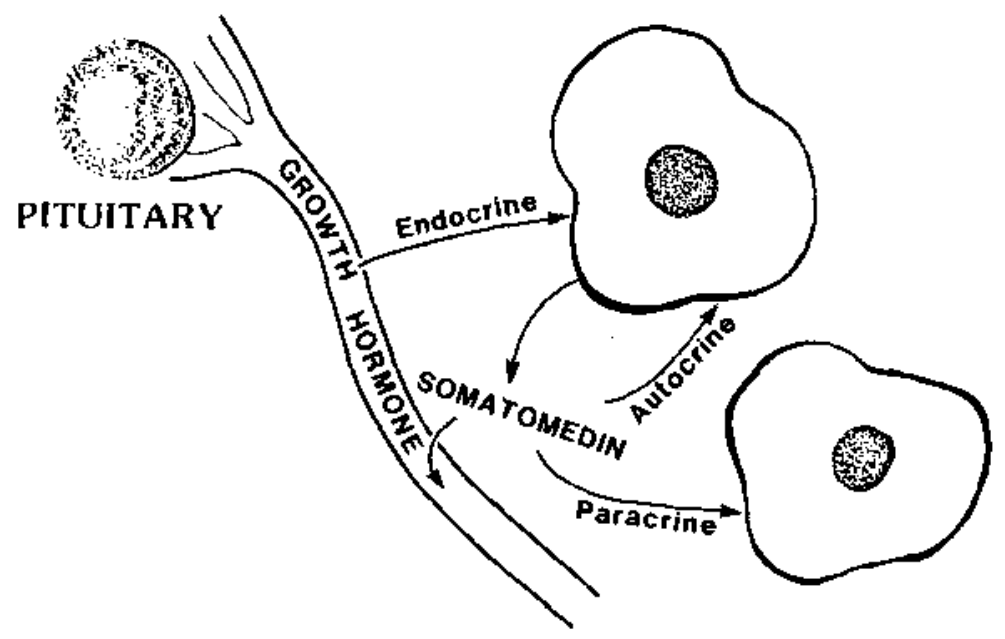

Figure 1 Comparison of autocrine/paracrine and endocrine control of cell growth by somatomedins.

tural requirements that are necessary to stimulate growth. IGF-II concentrations in plasma are much less dependent on growth hormone than are IGF-I concentrations, and their role in mediating changes in the anabolic response to nutrient intake is unknown. To propose a direct role for IGF-II in mediating changes in the anabolic response to nutrient intake is difficult because plasma levels of IGF-II have been shown to be unchanged even by extreme nutrient deprivation such as 10 days of fasting (20).

\section{Nutritional Control of IGF-I Synthesis and Secretion}

The possible role of nutrition in the regulation of IGFs first came to light when Grant et al observed that serum somatomedins (IGF) bioactivity was low in children with protein-calorie malnutrition, despite high growth hormone $(\mathrm{GH})$ values (29). The development of specific reagents that could reliably measure serum IGF-I concentrations by RIA enabled investigators to show that fasting of normal human subjects for 10 days resulted in a $70 \%$ fall in plasma IGF-I concentrations (12). The uncoupling between serum GH concentrations and GH action was confirmed by Merimee et al (53), who showed that after three days of fasting, normal subjects showed no change in serum IGF-I in response to GH injections. This finding suggested that the low somatomedin (IGF) observed in malnourished children was due to growth hormone resistance. Other hormones also appear to be involved in the fasting-induced decline in IGF-I as reflected in positive correlations between changes in serum T3 and insulin concentrations and changes in serum IGF-I during caloric restriction (9). 
The molecular mechanisms accounting for changes in blood concentrations of IGF-I during nutrient deprivation have been the focus of intense analysis. Rat models have been used for these studies so that tissues can be sampled and steady-state IGF-I mRNA levels can be analyzed. Because liver is believed to be the primary source of IGF-I in blood, this organ has been studied most intensely. When rats are fasted for three days they experience marked reductions in serum IGF-I and in binding of growth hormone to its receptor (46). This reduction in growth hormone binding has been proposed as the primary mediator of growth hormone refractoriness. During refeeding, hepatic growth hormone binding increased at approximately the same rate as the serum IGF-I concentrations. The fasting-induced decline in $\mathrm{GH}$ binding may be an important mechanism for the decrease in serum IGF-I concentrations. Straus \& Takemoto (72) have recently shown that the decrease in $\mathrm{GH}$ receptors that occurs during fasting is accompanied by a parallel decrease in hepatic GH receptor mRNA abundance, indicating that regulation may occur at the transcriptional level.

In fasted rats, steady-state hepatic IGF-I mRNA levels decrease in comparison with well-fed controls, thus indicating that decreased transcription of IGF-I mRNA may be the mechanism mediating the decrease in blood IGF-I concentrations (24). Indeed Straus \& Takemoto (72) have shown that this fasting-induced reduction is accompanied by a direct reduction in the rate of IGF-I gene transcription. Refeeding produces a prompt increase in steadystate mRNA levels.

In contrast to the reduction in $\mathrm{GH}$ receptors that occurs during fasting, dietary protein restriction in rats appears to lower serum IGF-I concentrations by a different mechanism. Rats subjected to restriction of dietary protein $(5 \%$ instead of $15 \%$ protein diet) show consistent reductions of serum IGF-I concentrations, but only modest reductions in GH binding (47). Furthermore, when protein-restricted rats are treated with $\mathrm{GH}$ they exhibit marked attenuation of the serum IGF-I response (44) (Figure 2). Taken together, these findings suggest that protein restriction causes post-receptor resistance to the action of $\mathrm{GH}$, and that the low IGF-I is not mediated via reduced GH binding (50). Protein restriction also causes reduction of hepatic IGF-I mRNA commensurate with the decline in serum IGF-I (55), which suggests that the changes in serum IGF-I come about partly as the result of transcriptional events.

Lowe et al have shown that fasting induces significant reductions in IGF-I mRNA abundance in nonhepatic tissues such as kidney, muscle, gut, and brain, indicating that these changes are not restricted to hepatic IGF-I mRNA (42). Furthermore, IGF-I receptor mRNA appears to be up-regulated in many of these organs (42). Protein deprivation in preweaning rat pups also reduces IGF-I mRNA abundance, thereby implicating pre-translational mechanisms (55). When young pups are fed a protein-restricted diet by gastrostomy their 


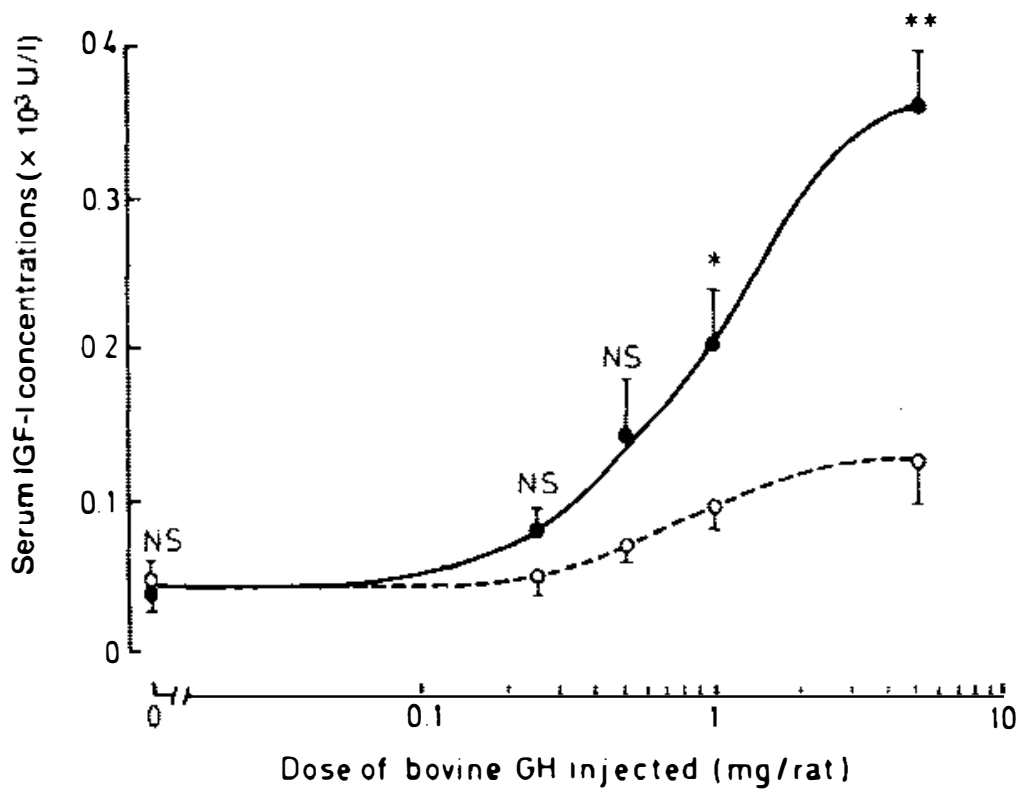

Figure 2 Response of serum IGF-I to GH in protein-restricted rats. Normal rats were fed a normal (closed circles) or a 5\% (open circles) protein diet for seven days and were given GH in the dosage indicated. The results show significant attenuation of the serum IGF-I response in the protein-restricted animals.

weight gain and tail lengths are less than those of control animals fed a normal diet. Correlations can be made between liver mRNA abundance and weight gain $(r=0.614)$, increases in tail length $(r=0.579)$, and plasma IGF concentrations $(r=0.56)$. The effect of protein deprivation appears to be age-dependent, since it is less profound in older animals (25).

The effect of energy deprivation on these molecular mechanisms has not been studied extensively. Several investigators have examined the effect of experimental diabetes as a model of energy restriction $(8,28,45,48,49)$. Maes et al showed that diabetes had no effect on $\mathrm{GH}$ receptor number in intact or hypophysectomized rats; their serum IGF-I responses to GH were impaired, however, suggesting that diabetes had caused a post-receptor defect (48). Goldstein et al have shown that experimental diabetes results in a reduction in hepatic IGF-I mRNA abundance, and they suggest that these changes contribute to reduction in serum IGF-I (28). Bornfelt et al have confirmed this finding in diabetic rats and have shown the IGF-I mRNA abundance is also reduced in kidney, heart, and diaphragm (8).

To determine if the reduction in the serum IGF-I response to GH is the sole mechanism resulting in growth retardation in protein-restricted rats, IGF-I has been administered to fasting mice and rats as well as to rats fed $5 \%$ protein 


\section{NUTRITIONAL REGULATION OF THE GH/IGF-1/IGF BINDING PROTEIN CASCADE}

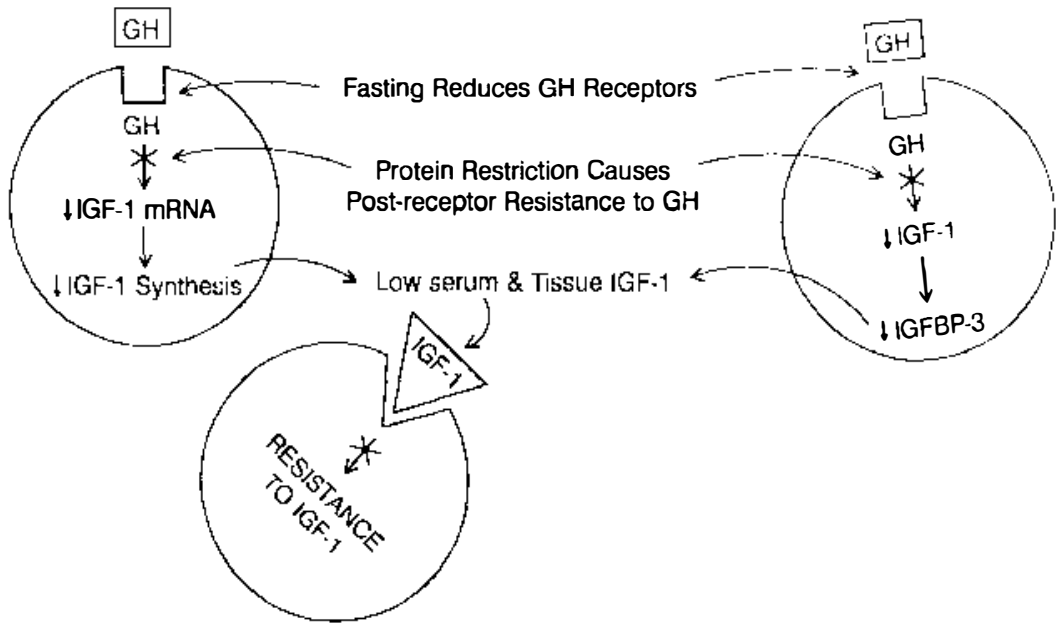

Figure 3 Sites in the GH/IGF-I/IGF binding protein cascade at which nutrient restriction appears to exert effects that lead to attenuation of growth. During fasting, GH receptors are decreased, and this may impair GH action. During protein restriction, GH binding is not diminished, but there is post-receptor resistance to the action of $\mathrm{GH}$. Nutrient restriction also decreased IGF binding protein-3, the principal serum carrier of IGFs. This, in tum, reduces serum IGF concentrations. Finally, protein restriction causes resistance of some tissues to the growth-promoting effects of IGF-I.

diets. If IGF-I is infused into starved mice (58) at a rate that maintains IGF-I levels similar to those in nonstarved animals, the rate of weight loss can be attenuated significantly for $36 \mathrm{hr}$. In contrast, $\mathrm{GH}$ has no effect. This finding suggests that the IGF-I has a direct role in mediating the fasting-induced changes in body mass. IGF-I infusion into rats who are fasted causes a reduction in protein degradation but produces no change in protein synthesis (37). Likewise, infusion of IGF-I into rats fed $5 \%$ protein diets does not restore the normal rate of increase in tail length, weight, or tibial epiphyseal width (76). This observation suggests that protein deficiency not only lowers serum IGF-I concentrations in response to $\mathrm{GH}$ but also produces refractoriness to IGF-I action. Interestingly, protein-deficient rats infused with IGF-I increase their serum IGF binding protein-3 (IGFBP-3) concentrations, suggesting that some actions of IGF-I are not impaired. Hirschberg \& Kopple showed that renal plasma flow increases when IGF-I is infused into in fasted rats, which suggests that this response is also maintained in kidney (33).

In summary, nutrient restriction appears to produce resistance to IGF-I and to $\mathrm{GH}$ action, and the mechanisms that mediate this resistance may be manifest at multiple points in the IGF biosynthetic pathway (Figure 3 ). IGF 
synthesis is impaired in the liver during fasting because of reduction of growth hormone receptors. Less stringent diet manipulations such as protein restriction appear to cause post-receptor defects in $\mathrm{GH}$ action. Basal rates of transcription, however, are reduced by protein restriction in rapidly growing rats, but basal levels of transcription are maintained in adult rats, and translation of IGF-I mRNA appears to be impaired. Finally, impairment of IGF-I action appears to occur at the cellular level, and delivery of IGFs out of the vascular compartment to tissues may be impaired in animals fed 5\% protein diets.

\section{Nutritional Control of Plasma Concentrations of IGF-I in Humans}

Reports of the changes in serum concentrations of IGF-I in response to dietary restriction in normal human subjects have revealed striking decreases in serum IGF-I. To define the macronutrient requirements necessary to maintain a normal serum IGF-I concentration, Isley et al fasted normal subjects for five days and then refed them three separate test diets containing different amounts of protein and energy. Fasting caused a $67 \%$ fall in IGF-I (35). Refeeding a control diet containing $35 \mathrm{kcal}$ and $1 \mathrm{~g}$ protein per kilogram ideal body weight (IBW) increased the IGF-I values to more than $70 \%$ of control values in 5 days (approximately 8 days are required to return to $100 \%$ of the control level). In contrast, if the subjects were refed a protein-deficient, energysufficient diet ( $40 \%$ of the recommended daily protein intake), the IGF-I increased to $55 \%$ of control values in 5 days, significantly less than the increase with the control diet (35) (Figure 4). If the subjects received a diet in which energy and protein were restricted, the values continued to decline over the next 5 days. The change in IGF-I during each fast-refeed cycle correlated with the mean daily nitrogen balance $(r=0.90)$. This correlation, however, did not appear to hold for changes in absolute protein balance. Rather, it reflects the acute directional changes in nitrogen balance that occur during fasting and refeeding. This finding suggested that measurement of IGF-I concentrations might predict whether a diet was adequate to significantly improve protein balance.

To further define the amounts of food needed to effect these changes, normal volunteers were fasted for 5 days and then refed test diets during sequential 9-day periods. One set of these diets contained adequate energy but incremental amounts of protein, while the other set contained adequate protein, with incremental amounts of energy. Fasting for 5 days caused a 70-75\% decline in IGF-I (36). During the 9-day refeeding periods, diets of the lowest energy and protein content resulted in minimal changes in IGF-I. If $0.2 / \mathrm{kg}$ IBW protein was refed (adequate energy), a statistically significant $28 \%$ rise in IGF-I occurred; but if $11 \mathrm{kcal} / \mathrm{kg}$ was fed (adequate protein), there 


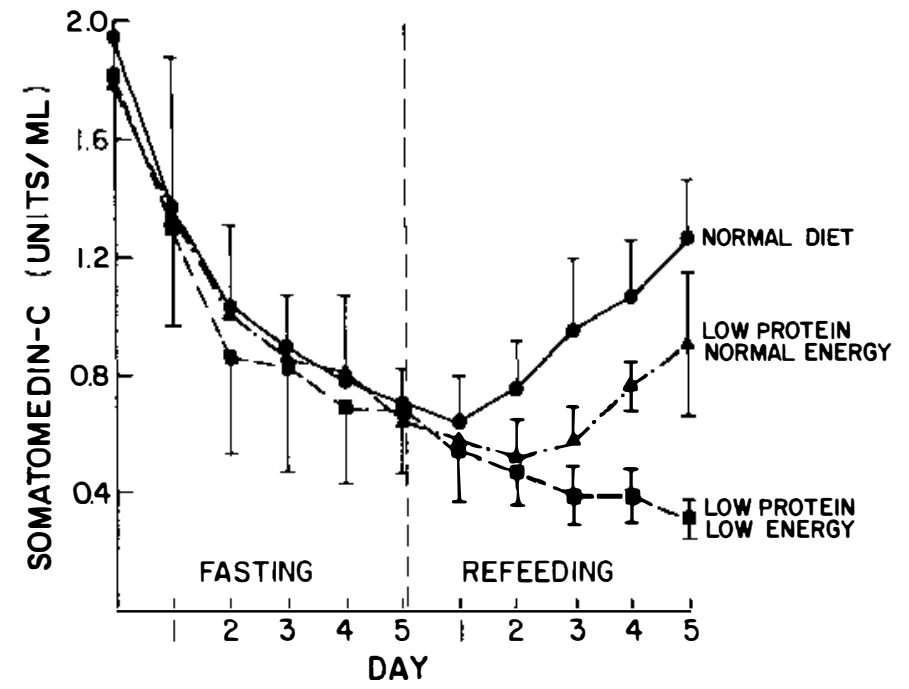

Figure 4 Change in somatomedin-C in response to fasting and refeeding. Five normal weight volunteers were fasted for 3 separate 5-day intervals and then were refed diets consisting of $1.0 \mathrm{~g}$ protein and $35 \mathrm{kcal} / \mathrm{kg}$ (normal diet), $0.4 \mathrm{~g}$ protein and $35 \mathrm{kcal} / \mathrm{kg}$ (low protein), or $0.4 \mathrm{~g}$ protein and $11 \mathrm{kcal} / \mathrm{kg}$ (low protein, low energy). The results show that combined energy and protein restriction prevents any increase in somatomedin-C in response to refeeding, whereas protein restriction attenuates the somatomedin- $\mathrm{C}$ response.

was no significant change in IGF-I. These findings suggest that the minimal requirement for calories is absolute and that a threshold quantity of energy must be provided for normal volunteers to increase their plasma concentrations of IGF-I. In contrast, at each level of protein intake (adequate energy) an incremental increase in serum IGF-I occurred. Specifically, the IGF-I values achieved at $0.4 \mathrm{~g} / \mathrm{kg}$ IBW were significantly greater than those achieved at $0.2 \mathrm{~g} / \mathrm{kg}$. IGF-I was normalized when $1 \mathrm{~g}$ protein per kilogram IBW was ingested. In terms of energy, the subjects had to be refed $18 \mathrm{kcal} / \mathrm{kg}$ IBW to obtain a significant increase in serum IGF-I, and maximal concentrations were achieved at $25 \mathrm{kcal} / \mathrm{kg}$ IBW. In this study also, an excellent correlation was found between changes in IGF-I induced with each diet and the acute directional change in nitrogen balance.

Although we assumed that the nutritionally dependent changes in plasma IGF-I were due to refractoriness to $\mathrm{GH}$, the precise degree of dietary restriction needed to produce GH refractoriness was not defined. Therefore, we have carried out studies to test the effect of caloric restriction on the IGF-I response to growth hormone. If obese subjects are fed a diet containing 24 $\mathrm{kcal} / \mathrm{kg}$ IBW, no change in basal serum IGF-I levels is observed over a period of 3 weeks (14). If exogenous growth hormone is administered, a 2.8 -fold 


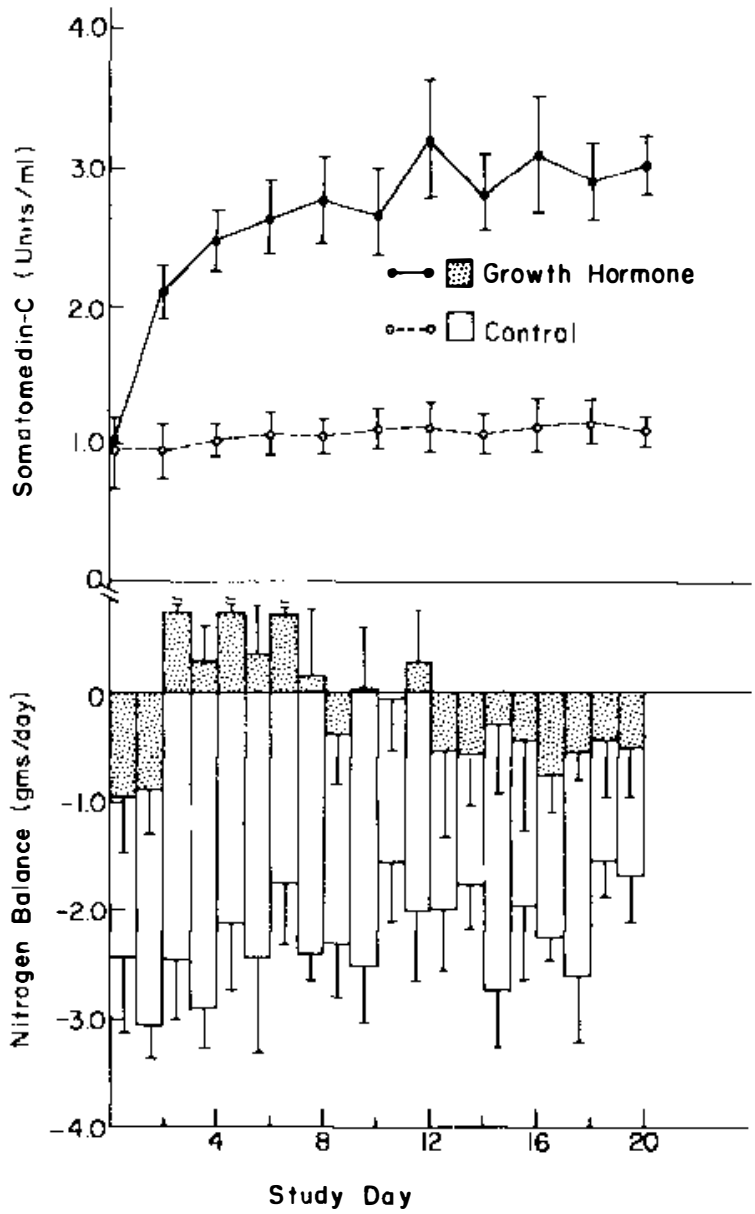

Figure 5 Changes in nitrogen balance and somatomedin-C (IGF-I) responses to growth hormone. GH was administered $(0.1 \mathrm{mg} / \mathrm{kg}$ ideal body weight q.o.d.) to obese subjects who were fed a calorically restricted diet $(24 \mathrm{kcal} / \mathrm{kg}$ per day). The results show that $\mathrm{GH}$ was capable of inducing an anabolic response under these conditions.

increase in serum IGF-I concentrations is observed indicating minimal or no attenuation in plasma IGF-I responsiveness to GH (Figure 5). All subjects entered positive nitrogen balance while receiving $\mathrm{GH}$, which indicates that this $24 \mathrm{kcal} / \mathrm{kg}$ diet had exerted little or no effect on their responsiveness. When more severe caloric restriction is imposed, however, effects are observed. In obese subjects fed $18 \mathrm{kcal} / \mathrm{kg}$ IBW for a period of 11 weeks and given GH every other day at a dose of $0.1 \mathrm{mg} / \mathrm{kg}$ IBW, IGF-I responses were normal at the beginning of $\mathrm{GH}$ therapy (approximately 3.1-fold increase) 
(69). Likewise, these subjects achieved positive nitrogen balance, but this response was attenuated over time, and after 5 weeks no difference in nitrogen balance between $\mathrm{GH}$ treated and control diet-restricted subjects was observed. Since IGF-I responsiveness remained for the entire 11 weeks, we concluded that the subjects had become refractory to IGF-I after 5 weeks. This observation in humans may be comparable to that seen in rats fed 5\% protein diets, who did not grow when infused with IGF-I, and suggests that an early effect of caloric restriction is attenuation of IGF-I responsiveness. Manson \& Wilmore also noted that normal-weight subjects fed a similar level of energy could respond to GH with a 2.1-fold increase in IGF-I (51).

To determine the degree of caloric restriction required to attenuate the IGF-I response to $\mathrm{GH}$, we fed obese subjects a diet containing $12 \mathrm{kcal} / \mathrm{kg}$ IBW and administered growth hormone. These subjects had a prompt IGF-I response to $\mathrm{GH}$, although it was significantly attenuated compared to the response of subjects that were fed $18 \mathrm{kcal} / \mathrm{kg} \mathrm{IBW}$, (i.e. a 1.8 -fold compared to a 3.1 -fold increase) (70). Unlike the response of subjects fed $18 \mathrm{kcal} / \mathrm{kg}$, the IGF-I response of subjects fed $12 \mathrm{kcal} / \mathrm{kg}$ began to attenuate quickly. After three weeks no significant differences were found between plasma IGF-I concentrations in the growth hormone-treated versus nongrowth hormonetreated subjects (70). Attenuation of nitrogen retention was significant, so that by the third week no differences in urinary nitrogen excretion were found between control and growth hormone-treated subjects. These findings suggest that more severe caloric restriction results not only in refractoriness of the IGF-I synthetic mechanism but also in refractoriness to IGF-I at the tissue level. Whether or not this refractoriness is mediated at the translational level or transcriptional level is unknown.

We have observed that the attenuation of the IGF-I response can be partially overcome by increasing the dose of growth hormone (67). When we gave twice as much growth hormone as in our previous studies, IGF-I responsiveness was sustained, but by the third week the nitrogen balance response began to attenuate, suggesting that the subjects had become refractory to IGF-I during the last two weeks of GH administration (67).

To further elucidate the role of nutrients in the development of sensitivity to growth hormone, we have studied the effect of refeeding of essential amino acids in increasing IGF-I secretion after fasting (13). Normal subjects were fasted for five days, then refed test diets containing approximately one half of a normal nitrogen intake. In one diet, $80 \%$ of the nitrogen was supplied as essential amino acids while in the other $80 \%$ was supplied as nonessential amino acids (13). After five days of refeeding, serum IGF-I was significantly greater in the subjects fed essential amino acids than in those fed nonessential amino acids. The final concentration of IGF-I was approximately $22 \%$ higher with the essential amino acid diet, indicating that ingestion of essential amino 
acids is required to attain an optimal IGF-I response to refeeding. As in other studies, an excellent correlation was found between changes in nitrogen balance that were induced by protein restriction and changes in blood IGF-I concentrations.

To determine if measurements of serum IGF-I have utility in predicting the responses of catabolic patients to refeeding, seven chronically undernourished subjects, most of whom had decreased nutrient absorptive capacity, were given hyperalimentation therapy (16). These subjects had lost between 3 and $21 \mathrm{~kg}$ in the year prior to study. All subjects were more than $10 \%$ below IBW at entry into the study. The nutrient repletion was accomplished by enteral or parenteral feedings, or both. The caloric intake ranged between 32.7 and 42.6 nonprotein $\mathrm{kcal} / \mathrm{kg}$ and the nitrogen intake was between 0.22 and $0.34 \mathrm{~g} / \mathrm{kg}$. The subjects' mean serum IGF-I concentration was approximately $0.67 \pm$ $0.15 \mathrm{U} / \mathrm{ml}$ and rose 3 -fold to $1.8 \pm 0.44 \mathrm{U} / \mathrm{ml}$ after 10 days of hyperalimentation therapy. The increase in serum IGF-I correlated with the change in cumulative nitrogen balance $(r=0.88)$. In contrast to the IGF-I results, no change in transferrin, retinol-binding protein, or prealbumin was noted during therapy. Following their peak IGF-I response after 10 days of nutrient repletion, the subjects had a decline in IGF-I despite continued hyperalimentation therapy. An overshoot phenomenon such as we observed has been described for protein turnover by Golden et al while refeeding children with protein/ calorie malnutrition (27). Our findings suggest that, as in normal individuals, changes in protein balance may correlate with changes in IGF-I concentrations during therapy of malnourished patients. These findings were confirmed by Donahue \& Phillips (22), who showed that nutritional support therapy of 15 hospitalized malnourished patients caused a $264 \%$ increase in serum IGF-I concentrations, but produced no significant change in albumin or transferrin. Changes in IGF-I correlated with changes in nitrogen balance in that study (22). These findings are supported by recent studies showing that IGF-I levels correlate with improvement in nitrogen balance in critically ill patients (32) and with body size in low birth weight infants (54).

To determine the role of excessive energy expenditure on nitrogen balance and serum IGF-I, normal subjects were exercised intensely for a period of one week but were maintained on a diet containing normal amounts of energy (35 $\mathrm{kcal} / \mathrm{kg}$ ) (66). The intensive exercise was sufficient to account for the expenditure of $13 \mathrm{kcal} / \mathrm{kg}$ of energy. This energy deficit resulted in a decrease in serum IGF-I concentrations of approximately $40 \%$ despite the fact that these exercising subjects should have had increased growth hormone secretion. Likewise, if these same subjects remained sedentary and were fed a diet with an equivalent degree of energy restriction (e.g. $22 \mathrm{kcal} / \mathrm{kg}$ ), they experienced approximately the same reduction in serum IGF-I concentrations. This finding indicates that loss of calories through utilization during exercise results in the 
same decrement in IGF-I concentration as does dietary-induced caloric restriction. This study also showed that protein was conserved in the exercising subjects. Specifically, during the last 3 days of diet restriction, daily nitrogen balance was $-3.50 \pm 1.73 \mathrm{~g}$ per day, whereas it was $-1.60 \pm 1.07$ $\mathrm{g}$ per day during exercise $(p<0.05)$.

Studies on the effects of GH on IGF-I secretion and the effects of IGF-I on protein balance are limited in patients who are catabolic because of severe medical and surgical illnesses. Ward et al (81) showed that postoperative patients whose energy intake was restricted severely (e.g. $400 \mathrm{kcal}$ per day) responded to $\mathrm{GH}$ with a significant increase in protein synthesis. Although the rate of protein breakdown also increased, the increase in protein synthesis exceeded the protein breakdown, and the subjects entered positive protein balance. Zeigler et al showed that GH improved nitrogen balance by $3.4 \mathrm{gm}$ per day in postoperative patients who were receiving $1100 \mathrm{kcal}$ per day (83). We studied 7 malnourished patients with undernutrition associated with chronic obstructive pulmonary disease (COPD) who were between 78 and $89 \%$ of ideal body weight. All subjects had significant weight gain and improvement in nitrogen balance on GH (59). Nitrogen balance increased from 1.6 to $3.3 \mathrm{~g}$ per day, and, most importantly, muscle strength as assessed by measurement of inspiratory force showed a significant increase. These studies indicate that patients who are catabolic may benefit not only from nutritional supplementation but also from pharmacologic agents that increase IGF-I above the levels that can be achieved by supplementation of nutrients alone.

\section{Insulin-like Growth Factor Binding Proteins and Nutrition}

The insulin-like growth factor binding proteins (IGFBPs) are high affinity, soluble carrier proteins that circulate in blood and extracellular fluids and appear to control IGF transport, efflux from the vascular compartment, and association of IGF with cell surface receptors. Understanding their role in determining how nutrient intake may influence IGF-I and -II actions is critical, since they control availability of IGFs to tissues, and their secretion is also controlled by nutrient intake (5). IGFBP-1 is a $25-\mathrm{kDa}$ protein whose plasma concentrations fluctuate widely over a $24 \mathrm{~h}$ period (4). IGFBP- 2 is a $31-\mathrm{kDa}$ protein whose plasma concentrations are somewhat more stable than those of IGFBP-1 and are significantly higher in fetal than in postnatal life. IGFBP-1 binds IGF-I and -II with approximately equal affinity, whereas IGFBP-2 has an approximately threefold greater affinity for IGF-II. IGFBP-3 is a 53-kDa glycoprotein that associates with an acid labile, nonbinding subunit in serum and with IGF to form a $150-\mathrm{kDa}$ complex (6). This complex apparently prevents rapid vascular efflux of IGF-I and -II from the vascular compartment and stabilizes the concentrations of IGFs in blood. The primary 
function of IGFBP-3 may be to act as a carrier of IGFs in the circulation, whereas the primary functions of IGFBP-1 and -2 may be to transport IGF across the endothelial surface to specific cell types (3). If these proteins serve different functions, it is reasonable to assume that regulation of their secretion may be different. For example, growth hormone and IGF-I both induce the synthesis and secretion of IGFBP-3, and increase its concentrations in plasma (15). In contrast, IGFBP-1 and -2 are both suppressed by growth hormone (31), and IGF-I directly stimulates the secretion of IGFBP-2, whereas it often inhibits IGFBP-1 (77).

Nutrient intake is a major regulator of the plasma concentrations of these proteins. Prolonged fasting and/or protein deficiency results in significant reduction in serum IGFBP-3 concentrations (15). Likewise, refeeding either normal energy or normal protein intake will increase the concentrations of this peptide. IGFBP-3, however, is not affected by acute changes in nutrient intake, and its plasma concentrations remain stable throughout the day (5). The fact that IGFBP-3 is the major carrier of IGF-I probably accounts for the stability of IGF-I in blood. Protein restriction has also been shown to increase hepatic IGFBP-2 mRNA abundance, although its effects on the serum concentrations of IGFBP-2 are unknown (73). Other nutritional factors affecting IGFBP-2 are not well delineated, although states of extreme insulin deficiency, e.g. starvation, for nine days or uncontrolled diabetes have been shown to increase plasma concentrations. In contrast, acute alterations in caloric intake have minimal effects on plasma IGFBP-2 concentrations.

Unlike IGFBP-2 and -3, IGFBP-1 is markedly suppressed by ingestion of food. This change is believed to be due to insulin secretion, since infusion of insulin into normal subjects suppresses IGFBP-1 (75), and the degree of suppression correlates in clamp studies with the degree of insulin-stimulated glucose transport (74). In type I diabetics the magnitude of the nocturnal increase in plasma IGFBP-1 is greater in under-insulinized and less in overinsulinized patients (34). In normal subjects infused with glucose the suppression of IGFBP-1 correlates with stimulation of c-peptide $(r=0.74)(68)$. However, glucose itself appears to have some direct suppressive effect because infusion of isocaloric amounts of fructose (which does not stimulate c-peptide secretion) causes suppression of IGFBP-1 that is about one half that caused by glucose infusion. This result suggests that both insulin-dependent and insulin-independent factors control IGFBP-1 secretion (68). Changes in plasma IGFBP-1 are accompanied by changes in hepatic IGFBP-1 mRNA. Fasting and/or insulin deficiency result in increasing amounts of IGFBP-1 mRNA in rat liver, and this mRNA is reduced by manipulations that raise insulin secretion (57).

The rapidity of the insulin-induced fall of IGFBP-1 concentrations has led several investigators to suggest that this decline may be secondary to accelera- 
heart system with insulin plus IGFBP-1 caused accelerated IGFBP-1 transport across the extravascular space, whereas IGFBP-2 transport was unaffected (2). Thus, insulin may selectively stimulate the translocation of IGFBP-1 under the influence of caloric intake.

Changes in the plasma concentrations of binding proteins could lead to changes in tissue distribution of IGF-I and IGF-II. Davenport et al have shown that reduction of IGFBP-3 in pregnant rat plasma leads to a marked alteration in the rate of tissue clearance and metabolism of radiolabeled IGF-I (19). Changes in nutrient intake, therefore, may not only alter IGF-I synthesis but also may change its rate of transport and its clearance in tissues. All of these changes may have important effects on IGF action.

\section{Control of IGF Action by Binding Proteins}

The molecular mechanisms by which the IGFs improve protein balance and growth are not completely understood. Following their secretion, the IGFs are bound to the high affinity IGF carrier proteins. Both IGFBP-3 and IGFBP-1 are present in extracellular fluids and modulate IGF action at the surface of target cells $(21,28)$. IGF-binding proteins were originally thought to simply act as a reservoir, preventing saturation of receptors and maintaining a constant egress of IGF off the binding protein-IGF complex and onto cell surface IGF receptors. Experiments in cell culture, however, suggest that a more complex phenomenon exists. In human fibroblasts, for example, IGFBP-3 is synthesized but then resides on the cell surface for a period of time prior to its secretion into medium (43). IGFBP-3 has such high affinity for IGF-I, however, that it preferentially binds the IGF-I that is present in the medium, and possibly these two proteins are co-secreted by the fibroblast. Addition of exogenous IGF-I results in displacement of IGF-I from soluble IGFBP-3 and makes it available to bind to cell surface-associated type I IGF receptors and IGFBP-3 (43). Because IGFBP-3 in culture medium has a higher affinity for IGF-I than either cell-associated binding proteins or receptors, it directs the amount of growth factor that binds to either moiety. Likewise, if sufficient amounts of IGFBP-1 and IGFBP-2 become cell surface associated, they exhibit the same kinetic phenomenon.

The metabolic consequences of this alteration in binding are not understood completely; however, it is clear that IGFBP-3 can potentiate the response to IGF-I. When added exogenously to MDBK cells or cultured human fibroblasts, coequal amounts of IGFBP-3 and IGF-I result in approximately $40 \%$ potentiation of the effect of IGF-I alone on the rate of cell growth (18). This response also occurs in BHK cells (7). If excessive amounts of IGFBP-3 are added, however, inhibition of cell growth takes place, which suggests that some optimal rate of transfer of IGF-I from IGFBP-3 onto the receptor is 
possibility that nutritional control of IGFBP-3 secretion at the cellular level may be an important modulator of target tissue cell responsiveness and could be an important mediator of tissue refractoriness to IGF-I.

Like IGFBP-3, IGFBP-1 is also a potent bimodulator of growth responsiveness to IGF-I. When quiescent smooth muscle cells are exposed to IGFBP-1 plus IGF-1, a 5.6-fold potentiation in the rate of DNA synthesis is observed (23). This potentiation requires an unknown factor that is present in plateletpoor plasma and human spinal fluid (11). IGFBP-1 also competes with IGF-I for binding to cell surface receptors and can act as a growth inhibitor if added to serum-free medium at high concentrations. Because IGFBP-1 concentrations are inversely related to serum insulin concentrations and IGFBP-1 transport is facilitated by insulin, the immediate availability of this binding protein in the microenvironment as a carrier of IGF-I could provide a significant source of IGF-I for rapid potentiation of cell growth.

\section{Summary}

The secretion of both IGF-I and IGF-II, peptides that are structurally related to insulin, is linked to nutrient intake. These growth factors and their binding proteins appear to be major links between nutrient intake and cellular anabolic responses. Understanding the mechanisms by which nutrients control IGF synthesis and regulate transport to target tissues should permit the formulation of strategies for treatment of catabolic disorders. Understanding the alterations of such processes in catabolic states should enable development of better methods for nutritional repletion and wiser uses of anabolic agents in the treatment of these conditions.

\section{ACKNOWLEDGMENTS}

The authors gratefully acknowledge Jennifer O'Lear, who prepared the manuscript. This work was supported by grants HL36313, AGO2331, HDO8299, and HD26871 from the National Institutes of Health.

\section{Literature Cited}

1. Atkison, P. R., Weidman, E. R., Bhaumick, K. B., Bala, R. M. 1980. Release of somatomedin-like activity by cultured WI-38 human fibroblasts. Endocrinology 106:2006-12

2. Bar, R. S., Boes, M., Clemmons, D. R., Busby, W. H., Sandra, A., et al. 1990. Insulin differentially alters transcapillary movement of intravascular IGFBP-1, IGFBP-2 and endothelial cell IGF-binding proteins in rat heart. Endocrinology 127:497-99
3. Bar, R. S., Clemmons, D. R., Boes, M., Busby, W. H., Booth, B. A., et al. 1990. Transcapillary permeability and subendothelial distribution of endothelial and amniotic fluid IGF-binding proteins in rat heart. Endocrinology 127: 1078-86

4. Baxter, R. C., Cowell, C. T. 1987. Diurnal rhythm of growth hormoneindependent binding protein for insulinlike growth factors in human plasma. $J$. Clin. Endocrinol. Metab. 65:432--40 
5. Baxter, R. C., Martin, J. L. 1989. Binding proteins for insulin-like growth factors: structure, regulation and function. Prog. Growth Factor Res. 1:49-68

6. Baxter, R. C., Martin, J. L., Beniac, V. A. 1989. High molecular weight insulinlike growth factor binding protein complex: purification and properties of the acid-labile subunit from human serum. J. Biol. Chem. 264:11843-48

7. Blum, W. F., Jenne, E. W., Reppin, F., Kietzmann, K., Ranke, M. B., Bierich, J. R. 1989. Insulin-like growth factor I (IGF-I) binding protein complex is a better mitogen than free IGF-I. Endocrinology $125: 766-72$

8. Bornfelt, K. E., Amqvist, H. J., Enberg, B., Mathews, L. S., Norstedt, G. 1989. Regulation of insulin-like growth factor-I and growth hormone receptor gene expression by diabetes and nutritional state in rat tissues. J. Endocrinol. 122:651-56

9. Caufriez, A., Golstein, J., Lebrun, P., Herchuelz, A., Furlanetto, R., Copinschi, G. 1984. Relations between immunoreactive somatomedin- $\mathrm{C}$, insulin and $\mathrm{T} 3$ patterns during fasting in obese subjects. Clin. Endocrinol. 20:65-70

10. Clemmons, D. R., Elgin, R. G., Han, V. K. M., Casella, S. J., D'Ercole, A. J., Van Wyk, J. J. 1986. Cultured fibroblast monolayers secrete a protein that alters the cellular binding of somatomedin-C/insulin-like growth factor I. $J$. Clin. Invest. 77:1548-56

11. Clemmons, D. R., Gardner, L. I. 1990. A factor contained in plasma is required for IGF-binding protein-1 to potentiate the effect of IGF-I on smooth muscle cell DNA synthesis. J. Cell. Physiol. 145:129-35

12. Clemmons, D. R., Klibanski, A., Underwood, L. E., McArthur, J. W., Ridgway, E. C., Van Wyk, J. J. 1981. Reduction of plasma immunoreactive somatomedin- $\mathrm{C}$ during fasting in humans. J. Clin. Endocrinol. Metab. 53: 1247-50

13. Clemmons, D. R., Seek, M. M., Underwood, L. E. 1985. Supplemental essential amino acids augment the somatomedin-C/insulin-like growth factor-I response to refeeding after fasting. Metabolism 34:391-95

14. Clemmons, D. R., Snyder, D. K., Williams, R., Underwood, L. E. 1987. Treatment with growth hormone conserves lean body mass during dietary restriction in obese subjects. J. Clin. Endocrinol. Metab. 64:878-83

15. Clemmons, D. R., Thissen, J. P., Maes, M., Ketelslegers, J. M., Underwood, L.
E. 1989. Insulin-like growth factor-I (IGF-I) infusion into hypophysectomized or protein-deprived rats induces specific IGF binding proteins in serum. Endocrinology 125:2967-72

16. Clemmons, D. R., Underwood, L. E., Dickerson, R. N., Brown, R. O., Hak, L. J., et al. 1985. Use of somatomedinC/insulin-like growth factor I measurements to monitor the response to nutritional repletion in malnourished patients. Am. J. Clin. Nutr. 41:191-98

17. Clemmons, D. R., Underwood, L. E., Van Wyk, J. J. 1981. Hormonal control of immunoreactive somatomedin production by cultured human fibroblasts. J. Clin. Invest. 67:10-19

18. Cohick, W. S., McCusker, R. H., Clemmons, D. R. 1990. Insulin-like growth factor binding proteins (IGFBPs) modulate IGF-I binding and cell growth responses of MDBK cells. Presented to the Endocrine Soc., June 21, Atlanta, Georgia, Abstr. 284

19. Davenport, M. L., Clemmons, D. R., Miles, M. W., Camacho-Hubner, C., D'Ercole, A. J., Underwood, L. E. 1990. Regulation of serum insulin-like growth factor I (IGF-I) and IGF binding proteins during rat pregnancy. Endocrinology 127:1278-86

20. Davenport, M. L., Svoboda, M. E., Koerber, K. L., Van Wyk, J. J., Clemmons, D. R., Underwood, L. E. 1988. Plasma concentrations of insulin-like growth factor II (IGF-II) are not changed by short-term fasting and refeeding. $J$. Clin. Endocrinol. Metab. 67:1231-36

21. De Mellow, J. S. M., Baxter, R. C. 1988. Growth hormone dependent insulin-like growth factor binding protein both inhibits and potentiates IGF-I stimulated DNA synthesis in skin fibroblasts. Biochem. Biophys. Res. Commun. 156:199-204

22. Donahue, S. P., Phillips, L. S. 1989. Response of IGF-I to nutritional support in malnourished hospital patients: a possible indicator of short-term changes in nutritional status. Am. J. Clin. Nutr. 50:962-69

23. Elgin, R. G., Busby, W. H., Clemmons, D. R. 1987. An insulin-like growth factor binding protein enhances the biological response to IGF-I. Proc. Natl. Acad. Sci. USA 84:3254-58

24. Emler, C. A., Schalch, D. S. 1987. Nutritionally-induced changes in hepatic insulin-like growth factor I (IGF-I) gene expression in rats. Endocrinology 120:832-34

25. Fliesen, T., Maiter, D., Gerard, G., Underwood, L. E., Maes, M., Ketelsleg- 
ers, J. M. 1989. Reduction in insulinlike growth factor I by dietary protein restriction is age dependent. Pediatr. Res. 26:415-19

26. Furlanetto, R. W., Underwood, L. E., Van Wyk, J. J., D'Ercole, A. J. 1977. Estimation of somatomedin-C levels in normals and patients with pituitary disease by radioimmunoassay. J. Clin. Invest. 60:648-57

27. Golden, M., Waterlow, J. R., Picou, D. 1977. The relationship between dietary intake, weight gain, nitrogen balance and protein turnover in man. Am. J. Clin. Nutr. 30:1345-48

28. Goldstein, S., Sertich, G. J., Levan, K. R., Phillips, L. S. 1988. Nutrition and somatomedin. 19. Molecular regulation of insulin-like growth factor I in streptozotocin-diabetic rats. Mol. Endocrinol. 2:1093-1100.

29. Grant, D. B., Hambley, J., Becker, D., Pimstone, B. L. 1973. Reduced sulphation factor in undernourished children. Arch. Dis. Child. 48:596-600

30. Han, V. K. M., D'Ercole, A. J., Lund, P. K. 1987. Cellular location of somatomedin (insulin-like growth factor) messenger RNA in the human fetus. Science 236:193-97

31. Hardouin, S., Gourmelen, M., Noguiez, P., Seurin, D., Roghani, M., et al. 1989. Molecular forms of serum insulinlike growth factor (IGF)-binding proteins in man: relationship with growth hormone and IGFs and physiological significance. J. Clin. Endocrinol. Metab. 69:1291-1301.

32. Hawker, F. H., Stewart, P. M., Baxter, R. C., Borkmann, M., Tan, K., et al. 1987. Relationship between somatomedin-C/insulin-like growth factor I levels to conventional nutritional indices in critically ill patients. Crit. Care Med. 15:732-36

33. Hirschberg, R., Kopple, J. D. 1989. Evidence that insulin-like growth factor $I$ increases renal plasma flow and glomerular filtration rate in fasted rats. $J$. Clin. Invest. 83:326-30

34. Holly, J. M. P., Smith, C. P., Dunger, D. B., Howell, R. J. S., Chard, T., et al. 1989. Relationship between the pubertal fall in sex hormone binding globulin and insulin-like growth factor binding protein-I. A synchronized approach to pubertal development? Clin. Endocrinol. 31:277-84

35. Isley, W. L., Underwood, L. E., Clemmons, D. R. 1983. Dietary components that regulate serum somatomedin-C in humans. J. Clin. Invest. 71:175-82

36. Isley, W. L., Underwood, L. E., Clem- mons, D. R. 1984. Changes in plasma somatomedin-C in response to ingestion of diets with variable protein and energy content. J. Parenter. Enter. Nutr. 8: 407-11

37. Jacob, R., Barrett, E., Plewe, G., Fagin, K. D., Sherwin, R. S. 1989. Acute effects of insulin-like growth factor I on glucose and amino acid metabolism in the awake fasted rat. J. Clin. Invest. 83:1717-23

38. Kadowaki, T., Koyasu, S., Nishida, E., Tobe, K., Izumi, T., et al. 1987. Tyrosine phosphorylation of common and specific sets of cellular proteins rapidly induced by insulin, insulin-like growth factor I and epidermal growth factor in an intact cell. J. Biol. Chem. 262:734250

39. Kahn, C. R., White, M. F. 1988. The insulin receptor and molecular mechanisms of insulin action. J. Clin. Invest. 82:1151-56

40. Kaplowitz, P. B., D’Ercole, A. J., Underwood, L. E., Van Wyk, J. J. 1984. Stimulation by somatomedin-C of aminoisobutyric acid uptake in human fibroblasts: A possible test for cellular responsiveness to somatomedin. J. Clin. Endocrinol. Metab. 58:176-81

41. Leof, E. B., Wharton, W., Van Wyk, J. J., Pledger, W. J. 1982. Epidermal growth factor and somatomedin-C regulate $G_{1}$ progression in competent BALB/ c 3T3 cell. Exp. Cell Res. 141:107-15

42. Lowe, W. J., Adamo, M., Werner, H., Roberts, C. T., LeRoith, D. 1989. Regulation by fasting of insulin-like factor I and its receptor: Effects on gene expression and binding. J. Clin. Invest. 84:619-26

43. McCusker, R. H., Camacho-Hubner, C., Bayne, M. L., Cascieri, M. A., Clemmons, D. R. 1990. Insulin-like growth factor (IGF) binding to human fibroblast and globlastoma cells: The modulating effect of cell released IGF binding proteins (IGFBPs). J. Cell. Physiol. 144:244-53

44. Maes, M., Amand, Y., Underwood, L. E., Maiter, D., Ketelslegers, J. M. 1988. Decreased serum insulin-like growth factor I response to $\mathrm{GH}$ in hypophysectomized rats fed a low protein diet: Evidence for a post receptor defect. Acta Endocrinol. 117:320-26

45. Maes, M., Ketelslegers, J. M., Underwood, L. E. 1983. Low plasma somatomedin-C in streptozotocin-induced diabetes mellitus: Correlation with changes in somatogenic and lactogenic sites. Diabetes 32:1060-69

46. Maes, M., Underwood, L. E., Ke- 
telslegers, J. M. 1983. Plasma somatomedin-C in fasted and refed rats: Close relationship with changes in liver somatogenic $(\mathrm{GH})$ but not lactogenic (PRL) binding sites. J. Endocrinol. 97:243-52

47. Maes, M., Underwood, L. E., Ketelslegers, J. M. 1984. Low somatomedin-C in protein deficiency: Relationship with changes in liver somatogenic and lactogenic binding sites. Mol. Cell. Endocrinol. 37:301-9

48. Maes, M., Underwood, L. E., Ketelslegers, J. M. 1986. Low serum somatomedin-C in insulin-dependent diabetes: Evidence for a post receptor mechanism. Endocrinology 118:377-82

49. Maiter, D., Fliesen, T., Underwood, L. E., Maes, M., Gerard, G., et al. 1989. Dietary protein restriction decreases insulin-like growth factor-I (IGF-I) independent of insulin and liver growth hormone binding. Endocrinology 124: 2604-11

50. Maiter, D. M., Maes, M., Underwood, L. E., Fliesen, T., Gerard, G., Ketelslegers, J. M. 1988. Early changes in serum concentrations of somatomedin-C induced by dietary protein deprivation: Contributions of growth hormone receptor and post-receptor defects. J. Endocrinol. 118:113-20

51. Manson, J. M., Wilmore, D. W. 1986. Positive nitrogen balance with growth hormone and hypocaloric intravenous feeding. Surgery 100:188-97

52. Marshall, R. N., Underwood, L. E., Voina, S. J., Foushee, D. B., Van Wyk, J. J. 1974. Characterization of insulin and somatomedin receptors in human placental membranes. J. Clin. Endocrinol. Metab. 39:283-92

53. Merimee, T. J., Zapf, J., Froesch, E. R. 1982. Insulin-like growth factors in fed and fasted states. J. Clin. Endocrinol. Metab. 55:999-1002

54. Mitchell, M. L., Hermos, R. J., Feingold, M., Moses, A. C. 1989. The relationship of insulin-like growth factor-I to total thyroxine in normal and low birth weight infants. Pediatr. Res. 25:336-38

55. Moats-Staats, B. M., Brady, J. L., Underwood, L. E., D’Ercole, A. J. 1984. Dietary protein restriction in artificially reared neonatal rats causes a reduction in insulin-like growth factor I (IGF-I) gene expression. Endocrinology 125:236874

56. Nissley, S. P., Rechler, M. M. 1985. Insulin-like growth factors: biosynthesis, receptors and IGF-carrier proteins. In Hormonal Proteins and Peptides, ed.
C. H. Li, 12:127-203. New York: Academic

57. Ooi, G. T., Orlowski, C. C., Brown, A. L., Becker, R. E., Unterman, T. G., Rechler, M. M. 1990. Different tissue distribution and hormonal regulation of mRNAs encoding rat insulin-like growth factor binding proteins-1 and 2. Mol. Endocrinol. 4:321-28

58. O'Sullivan, U., Gluckman, P. D., Breier, B. H., Woodall, S., Siddiqui, R. A., McCutcheon, S. N. 1989. Insulinlike growth factor-I (IGF-I) in mice reduces weight loss during starvation. Endocrinology 125:2793-94

59. Pape, G. S., Friedman, M., Underwood, L. E., Clemmons, D. R. 1991. The effect of growth hormone on weight gain and pulmonary function in patients with chronic obstructive lung disease. Chest. In press

60. Phillips, L. S., Young, H. S. 1976. Nutrition and somatomedin. I. Effects of fasting and refeeding on serum somatomedin activity and cartilage growth activity in rats. Endocrinology 99:304 14

61. Rinderknecht, E., Humbel, R. E. 1978. The amino acid sequence of human insulin-like growth factor I and its structural homology with proinsulin. J. Biol. Chem. 253:2769-76

62. Rotwein, P., Folz, R. H., Gordon, J. I. 1987. Biosynthesis of human insulinlike growth factor I (IGF-I). J. Biol. Chem. 262:11807-12

63. Russell, W. E., Van Wyk, J. J., Pledger, W. J. 1984. Inhibition of the mitogenic effects of plasma by a monoclonal antibody to somatomedin-C. Proc. Natl. Acad. Sci. USA 81:238992

64. Salmon, W. D. Jr., Duvall, M. R. 1970. In vitro stimulation of leucine incorporation into muscle and cartilage protein by a serum fraction with sulfation factor activity: Differentiation of effects from those of growth hormone and insulin. Endocrinology 87:1168-80

65. Scheiwiller, E., Guler, H. P., Merryweather, J., Scandella, C., Maerki, W., et al 1986. Growth restoration of insulin-deficient diabetic rats by recombinant human insulin-like growth factor I. Nature 323:169-71

66. Smith, A. T., Clemmons, D. R., Underwood, L. E., Ben-Ezra, V., McMurray, R. 1987. The effect of exercise on somatomedin-C/insulin-like growth factor I concentrations. Metabolism 36: 533-37

67. Snyder, D. K., Underwood, L. E., Clemmons, D. R. 1990. The anabolic 
effects of growth hormone in obese dietrestricted subjects are dose dependent. Am. J. Clin. Nutr. 52:431-37

68. Snyder, D. K., Clemmons, D. R. 1990. Insulin dependent regulation of IGFBPI. J. Clin. Endocrinol. Metab. 71:163236

69. Snyder, D. K., Clemmons, D. R., Underwood, L. E. 1988. Treatment of obese, diet-restricted subjects with growth hormone for 11 weeks: Effects on anabolism, lipolysis and body composition. J. Clin. Endocrinol. Metab. 67:54-61

70. Snyder, D. K., Clemmons, D. R., Underwood, L. E. 1989. Dietary carbohydrate content determines responsiveness to growth hormone in energyrestricted humans. J. Clin. Endocrinol. Metab. 69:745-52

71. Stiles, C. D., Capone, G. T., Scher, C. D., Antoniades, H. N., Van Wyk, J. J., Pledger, W. J. 1979. Dual control of cell growth by somatomedin and plateletderived growth factor. Proc. Natl. Acad. Sci. USA 76:1279-84

72. Straus, D. S., Takemoto, C. D. 1990. Effect of fasting on insulin-like growth factor-I (IGF-I) and growth hormone receptor mRNA levels and IGF-I gene transcription in rat liver. Mol. Endocrinol. 4:91-100

73. Straus, D. S., Takemoto, C. D. 1990. Effect of dietary protein deprivation on insulin-like growth factor (IGF) I and II, IGF binding protein-2 and serum albumin gene expression in rat. Endocrinology 127:1849 -60

74. Suikkari, A.-M., Koivisto, V. A., Koistinen, R., Seppala, M., Yki-Jarvinen, H. 1989. Dose-response characteristics for suppression of low molecular weight plasma insulin-like growth factorbinding protein by insulin. J. Clin. Endocrinol. Metab. 68:135-40

75. Suikkari, A.-M., Koivisto, V. A., Rutanen, E.-M. Yki-Jarvinen, H., Karonen, S. L., Seppala, M. 1988. Insulin regulates the serum levels of low molecular weight insulin-like growth factor-binding protein. J. Clin. Endocrinol. Metab. 66:266-72

76. Thissen, J. P., Underwood, L. E., Maiter, D., Maes, M., Clemmons, D. R., Ketelslegers, J. M. 1991. Failure of IGF-I infusion to promote growth in protein-restricted rats despite normalization of serum IGF-I concentrations. Endocrinology 128:885-90

77. Thrailkill, K. M., Clemmons, D. R., Busby, W. H., Handwerger, S. 1990. Differential regulation of insulin-like growth factor binding protein secretion from human decidual cells by IGF-I, insulin and relaxin. J. Clin. Invest. 86: 878-83

78. Ullrich, A., Gray, A., Tam, A. W., Yang-Feng, T., Tsubokawa, M., et al. 1986. Insulin-like growth factor I receptor primary structure: comparison with insulin receptor suggests structural determinants that define functional specificity. EMBO J. 5:2503-12

79. Van Wyk, J. J. 1984. The somatomedins: biological actions and physiologic control mechanisms. In Hormonal Proteins and Peptides, ed. C. H. Li, 12:81125. Orlando, Fla.: Academic

80. Van Wyk, J. J., Underwood, L. E., Hintz, R. L., Voina, S. J., Weaver, R. P. 1974. The somatomedins: A family of insulin-like hormones under growth hormone control. Rec. Prog. Horm. Res. 30:259-318

81. Ward, H. C., Halliday, D., Sim, A. W. 1987. Protein and energy metabolism with biosynthetic human growth hormone after gastrointestinal surgery. Ann. Surg. 206:56-61

82. Zapf, J., Rinderknecht, E., Humble, R. E., Froesch, E. R. 1978. Nonsuppressable insulin-like activity (NSILA) from human serum: Recent accomplishments and their physiologic implications. Metabolism 27:1803-28

83. Ziegler, T. R., Young, L. S., Manson, J., Wilmore, D. W. 1988. Metabolic effects of recombinant human growth hormone in patients receiving parenteral nutrition. Ann. Surg. 208:6-16 